\title{
POT1 Gene
}

National Cancer Institute

\section{Source}

National Cancer Institute. POT1 Gene. NCI Thesaurus. Code C107655.

This gene plays a role in the regulation of telomere length. 